DOI: $10.19195 / 0137-1150.163 .60$

\author{
MILICA JAKÓBIEC-SEMKOWOWA \\ Uniwersytet Wrocławski, Polska \\ milica.semkow@gmail.com
}

\title{
Poetyckie rozważania o starości ręką kobiecą spisane. Desanka — Urszula — Elisaweta
}

\author{
Starość nie jest ani spokojna, ani dostojna. \\ Jest ciężka, brzydka, samotna, bezradna. \\ Fotografia jest jedyna bronia, która może coś zatrzymać ${ }^{1}$.
}

Przytoczona jako motto opinia Zofii Rydet, mistrzyni fotografii, odzwierciedla w swej pierwszej części powszechne, powielane często przekonanie dotyczące ostatniego etapu życia ludzkiego. Z prawdziwością tego stwierdzenia każdy musi się w pewnym momencie swej egzystencji zmierzyć, a doświadczanie starości będzie miało zawsze charakter indywidualny. $Z$ drugą częścią przytoczonej tu wypowiedzi przyjdzie nam podjąc dyskusję poprzez wskazanie innej, obok fotografii, broni, która pozwoli zatrzymać przykre objawy nieuniknionego, zmierzającego ku śmierci, procesu starzenia się i zneutralizować negatywne emocje przez uświadomienie sobie jego nieuchronności. Tym orężem w walce ze starością okażą się słowa ułożone w obrazy i figury poetyckie. Wiersze autorstwa kobiet-poetek stanowią nie tylko ich tarczę obronną, lecz także mają moc krzepiącą czytelników.

Literackie rozważania kobiet na temat starości rzadko stawały się przedmiotem dociekań i analiz naukowych. W lubelskim tomie Dojrzewanie do petni życia. Starość w literaturze polskiej i obcej ${ }^{2}$ zaledwie trzy opracowania poświęcone są kobietom (na 47!), przy czym poddany wnikliwej analizie intymny dziennik

${ }^{1}$ Wypowiedź Zofii Rydet, fotografki (1911-1997) przytoczona przez A. Zawadzką w artykule poświęconym artystce. A. Zawadzka, Ja jedna przedłużam życie, „Wysokie Obcasy” 10 maja 2008, nr 18 (471), s. 46.

${ }^{2}$ Dojrzewanie do petni życia. Starość w literaturze polskiej i obcej, red. S. Kruk, E. Flis-Czerniak, Lublin 2006. 
Elizy Orzeszkowej ${ }^{3}$ nie mieści się z całą pewnością w kręgu literatury pięknej, bohaterki zaś Gabrieli Zapolskiej": „,więdnące dziewczęta” i „krzepkie matrony” trudno traktować jako projekcję jej własnej postawy życiowej. Natomiast liczne odniesienia do wątków biblijnych i religijnych wyeksponowane przez Iwonę Łapińską w poezji Anny Kamieńskiej ${ }^{5}$ pozwalają spojrzeć na jej tom Życiu zmitowanie i Notatnik z ostatnich lat życia bardziej z perspektywy filozoficznej niż egzystencjalnej.

Imponująca bogactwem materiałów źródłowych Historia starości Jeana-Pierre'a Bois ${ }^{6}$, panoramicznie ukazująca wpływ przemian kulturowych na miejsce i rolę starych ludzi w społeczeństwach zachodnich, to raczej historia starców. Autor bardzo rzadko wspomina o starych kobietach, bo też do początku XX stulecia ich podrzędne miejsce w strukturze społecznej było ściśle określone. Pojawienie się w XX wieku autorek manifestujących swoją kobiecą osobowość było oczywiście wynikiem postępującej emancypacji. Problem „starszej kobiety”7, jej miejsca w kulturze i społeczeństwie, stał się natomiast przedmiotem rozważań andragogów dopiero w drugiej połowie ubiegłego stulecia. Autorki interesującego opracowania ,Starość" w narracjach kobiet $w$ drugiej połowie życia przywołują cenne dla niniejszych rozważań ustalenia dotyczące procesów psychicznych zachodzących w okresie późnej dorosłości autorstwa Marii Straś-Romanowskiej. Charakterystyczne dla tego etapu życia procesy i zdolności psychiczne to m.in. „zdolność ujmowania zjawisk z różnych perspektyw, dostrzeganie wielości prawd [...] i wpisanych w rzeczywistość paradoksów”, a także „potrzeba uporządkowania życia wobec doświadczenia przemijania, bezsilności wobec natury i losu" ". W podsumowaniu badań przeprowadzonych na grupie respondentek autorki wyróżniają trzy psychologiczne konsekwencje starości: poczucie osamotnienia, zmiana w sposobie myślenia i doświadczania rzeczywistości, skutkująca dystansem w stosunku do życia oraz tolerancją wobec jego paradoksów i niejednoznaczności, a także przeżywanie śmierci, która jawi się w postaci odejścia najbliższych, bądź jako nieuniknione następstwo własnego przemijania.

Przedmiotem niniejszej analizy będą wypowiedzi poetyckie trzech autorek, którym przyszło zmierzyć się z własnym doświadczeniem starości, poetek, które

${ }^{3}$ H. Bursztyńska, Eliza Orzeszkowa - Dnie, prywatność starości, [w:] Dojrzewanie..., s. $238-246$.

4 A. Janiak-Staszek, „Więdnace” dziewczęta $i$ „,krzepkie” matrony w twórczości Gabrieli Zapolskiej, [w:] Dojrzewanie..., s. 315-324.

${ }^{5}$ I. Łapińska, ,Życiu zmiłowanie”. O starości w poezji Anny Kamieńskiej, [w:] Dojrzewanie..., s. 505-510.

6 J.P. Bois, Historia starości. Od Montaigne'a do pierwszych emerytur, przeł. K. Marczewska, Warszawa 1996.

${ }^{7}$ Starsze kobiety w kulturze i społeczeństwie, red. E. Zierkiewicz, A. Łysiak, Wrocław 2005.

${ }^{8}$ M. Straś-Romanowska, Paradoksy rozwoju człowieka $w$ drugiej połowie życia a psychoprofilaktyka starości, za: A. Cieślik, A. Zubik, M. Bańczarowska, „Starośc”” w narracjach kobiet $w$ drugiej polowie życia, [w:] Starsze kobiety..., s. 36.

${ }^{9}$ Ibidem. 
łączy nie tylko sędziwy wiek, fakt uznawania ich za „pierwsze/prawdziwe damy poezji”, kumulujące nabywaną przez lata mądrość życiową z umiejętnością lirycznej eksploracji własnego ,ja” poetyckiego, ale też wyartykułowana w późnym wieku wciąż żywa pasja twórcza. Są to — przedstawiając je chronologicznie — bułgarska poetka Elisaweta Bagriana (1893-1991) ${ }^{10}$, serbska autorka Desanka Maksimović (1898-1993) oraz wrocławska współczesna poetka — Urszula Kozioł (ur. 1931).

W poezji pierwszej z nich, Elisawety Bagriany, po raz pierwszy w literaturze bułgarskiej przemówiła kobieta, manifestując szczerze i otwarcie swoją naturę ${ }^{11}$. Podobnie już w pierwszych tomikach poetyckich Desanki Maksimović krytycy dostrzegali ${ }^{12}$ spontaniczność i szczerość uczuć, afirmację życia i przyrody odbieranej wszystkimi zmysłami. Była szczera i bezpośrednia — jak trafnie zauważa Grzegorz Łatuszyński ${ }^{13}$ w posłowiu do tomu jej przekładów — zarówno wtedy, gdy dawała wyraz młodzieńczym fascynacjom, jak i później, gdy patrzyła na świat oczyma dojrzałej kobiety. Warto dodać, że szczególnie interesujące w kontekście rozważań o starości tomy poetyckie obu sędziwych autorek ukazały się niemal w tym samym czasie: Kontrapunkti Bagriany w 1972, a Nemam više vremena D. Maksimović w 1973 roku.

Wspólną płaszczyzną pozwalającą na zestawienie autorek z Bałkanów jest zarówno przynależność pokoleniowa, jak i szczególna rola, jaką odgrywały w swoich literaturach narodowych podporządkowanych patriarchalnym modelom kulturowym. Otwartość, z jaką w młodości mówiły o swoich przeżyciach, była świadomym podważaniem tabu. Po latach równie odważnie podjęły temat własnej starości, jednoznacznie kwestionując stereotyp „dobrej babci” lub złośliwej „wiedźmy”. Z wrocławską poetką — należącą do następnego już pokolenia — łączy je także świadomość powołania poetyckiego, profesji, której pozostają wierne mimo upływu lat.

${ }^{10}$ Serdecznie podziękowania składam prof. Celinie Judzie za pomoc w wyborze wierszy Bagriany i Mikołajowi Delineszewowi za pomoc w ich pełnym zrozumieniu.

11 М. Цанева, Речник по нова българска литература (1978-1992), Хемус 1994, http:/ www.slovo.bg/showbio.php3?ID=183 [dostęp: 2.03.2015]. Polskie opracowania jej twórczości są mniej niż skromne, podobnie jak przekłady. Jedyny niewielki tomik to: E. Bagriana, Poezje, wybr. J. Śpiewak, przekł. zbior., Warszawa 1961.

12 Ogromna literatura o Desance Maksimović opracowana przez A. Vraneš i Lj. Đorđević znalazła się w X tomie edycji Целокупна дела (Литература о Десанки Максимовић, s. 443 570, przypis 14). Całościowo opracował jej twórczość Slobodan Ž. Marković. С.Ж. Марковић, Кьижевно стваралаштво Десанке Максимовић, Београд 1998; por. też np. М. Егерић, Песништво Десанке Максимовић - призори лирске доброте и самилости, [w:] Д. Максимовић, Изабране песме, Београд 1998; Д.М. Јеремић, Класични песник Десанка Максимовић, [w:] Д. Максимовић, Слово о љубави, Београд 2002.

13 Por. G. Łatuszyński, Pierwsza Dama poezji serbskiej, [w:] D. Maksimović, Poezje, wybór wierszy, przekład i posłowie G. Łatuszyński, Warszawa 2013, s. 135-146. Zdecydowana większość cytowanych tu tekstów nie znalazła się w tym tomie. 
Fizyczne i biologiczne oznaki schyłku życia dostrzega Desanka Maksimović, obserwując przede wszystkim najdrobniejsze realia otaczającej ją przyrody. Liryk Žena i lipa z 1992 roku oparty zostaje na prostym porównaniu:

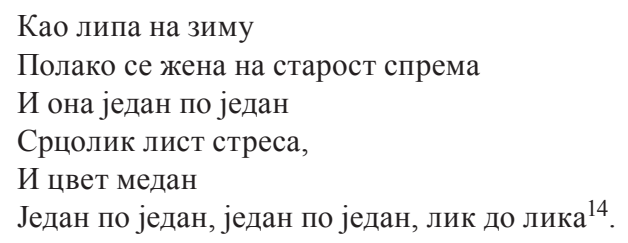

To proste porównanie odwołuje się do naturalnych procesów zachodzących w przyrodzie, którym podlega także kobieta. W innym tekście (1983) poetka stosuje „odwróconą" metaforę; róże w jesiennym ogrodzie więdną „po ludzku” i rozpaczliwie bronią się przed starością („,...руже људски бледе и смежуране/ на сунцу јесењем лицемерну и шкрту/ очајнички се од старости бране" [III, 67]), krzewy czarnego bzu wyglądają jak wiejskie staruszki z opuszczonymi głowami, a słoneczniki jak zdemobilizowani żołnierze grzejący przetrącone kręgosłupy. U podstaw tych obrazów poetyckich, podobnie jak w poprzednim przykładzie, leży przekonanie o wspólnym w przyrodzie procesie przemijania.

Fizyczne objawy starzenia się ludzkiego ciała są przedmiotem znacznie wcześniejszego (z 1973 roku), poetyckiego opisu w liryku Ruka:

Тешка, пуна коштаних опиљака,

лежи у крилу старачка рука.

На њој је оцртана

Модра грана вена

И азбука бора, замршена.

Moment ożywienia pojawi się w kontakcie z główką dziecka („,засветли ce и прене као заливена биљка... опиљци костију се споје, легне зглоб у зглоб”), ale

чим дете оде

Рука опет клоне

И падне у крило

Као у гроб (II, 411).

Kontakt z małym dzieckiem jest też dla Elisawety Bagriany impulsem do konfrontacji ,jesieni życia” z „wiosną”. Krótki liryk Дememo (Dziecko) poświęcony nowonarodzonemu prawnukowi Lubomirowi, utrzymany jest jednak w całości w radosnej tonacji:

Едно дете [...]

влива радост

${ }^{14}$ D. Maksimović, Žena i lipa, [w:] Д. Максимовић, Целокупна дела, red. Д. Иванић, књига прва, t. III, s. 522, http://zdm.nb.rs/dokumenti/tomIII.pdf [dostęp: 10.02.2015]. Wszystkie cytaty z poezji D. Maksimović pochodzą z wzorcowo przygotowanej internetowej edycji jej dzieł i oznaczane będą w tekście skrótem zawierającym nr tomu i stronę. 


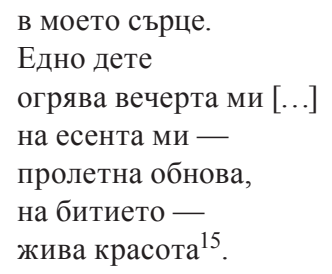

Ten sam temat starczej ręki powróci jeszcze parokrotnie w poezji Desanki Maksimović. W wierszu Rentgenski snimak z 1983 roku poetka patrząc na zdjęcie rentgenowskie i podziwiając zarysowane w nim kości, wyraźne jak w szkolnym atlasie, zachwyca się doskonałością połączeń: „са колико су уметности - поспајане у клештанца, - у ножице и полуге" (III, 84). Przywołane jednocześnie porównanie do wiązki chrustu bukowego kojarzy się z przemijalnością i kruchością ludzkiej egzystencji. Kolejny raz pojawi się ten motyw w wierszu Uz pastirsku vatru (Przy pasterskim ognisku, 1983). Tym razem jednak poetkę nie interesują fizyczne objawy starości; patrząc na płonące w ogniu gałęzie, które ogień na chwilę powraca do życia, stwierdza: „А моје руке,/ сумњам да ће моје руке/ поново каква ватра запалити" (III, 77). Jeszcze raz starcza ręka pojawi się w wierszu Uskrsnuće (Zmartwychwstanie, 1991): „nieco bledsza i cieńsza”, wysuszona jak koryto rzeki, z wytatuowanym wewnątrz dłoni losem (III, 506).

Dalsze uszczegółowienie obserwacji nadchodzącej starości następuje wówczas, gdy serbska poetka przygląda się sobie i bliskiej sobie osobie. W wierszu Prvo smo mislili (Najpierw myśleliśmy, 1973) z niedowierzaniem, jakby zaskoczeniem wymienia drobne przejawy niedyspozycji fizycznych, próbuje nimi tłumaczyć inną niż dawniej wrażliwość. ,Jakaś choroba żołądka” — może na skutek jedzonych w dzieciństwie niedojrzałych owoców, wysuszony nerw oczny — od miejskiego kurzu i dymu, ,pod powiekami ciernie i ziarnka piasku”, a wreszcie „bezsenność, niedowidzenie i chore serce” nie pozwalają żyć tak jak dawniej, są po prostu objawem nadchodzącej starości:

Сад више никога и ништа

не оптужујемо

за бесанице, за губљење вида,

болесно срце, изненадне сете,

смешимо се сад с помало туге,

помало стида

када гласници старења налете (II, 397).

Obrazy fizycznych objawów starości w poezji Elisawety Bagriany są niemal nieobecne; wyróżnia się w tym kontekście wiersz Cmapama трепетлика (Stara osika) poświęcony matce, oparty na rozbudowanej metaforze — stare drzewo, na pozór delikatne i kruche opiera się wszelkim burzom; okaleczone przez czas i pioruny: „z korą popękaną, skostniałą na swoich dziurawych ramionach trzyma ogromne, ciężkie gałęzie i młode pędy"

15 Е. Багряна, Стихотворения, София 1986, s. 121. 
С кори напукани, вкостени,

На кухите си рамене

Дьржи огромни тешки клони

И новорасли вейки ${ }^{16}$.

Pesymistyczny ton rozważań o różnych zewnętrznych objawach starości obecny jest także w wydanym w 2005 roku tomiku poetyckim Supliki wrocławskiej poetki Urszuli Kozioł. Poetka stwierdza lapidarnie: ,jest mnie coraz mniej w życiu"17, by w innych wierszach przejść do bardziej szczegółowych opisów. Fizyczną brzydotę starości, „pokraczność zniedołężniałej egzystencji”, poetka kreśli precyzyjnie w Małym traktacie o Bożych niesprawiedliwościach. Pyta gniewnie:

Nie dość więc, że stary człowiek szpetnieje, kurczy się, marszczy i przecieka jak dziurawy garnek, nie dość, że traci zęby i włosy, musi nadto jeszcze tracić pamięć i rozum? Zdolność stanowienia o sobie? Ba, zdolność utrzymania się na nogach, dźwignięcia się na zwykły stopień, bo nawet głupie schody uzurpują sobie teraz prawo rządzenia jego krokami? ${ }^{18}$

Postępujące zniedołężnienie prowadzi podmiot liryczny do głębokiego zwątpienia skierowanego przeciw Bogu: „Czy to na pewno On, ten sam, zesłał nam kiedyś śpiewającego ptaka, perłę i gwiazdę [...] porywy duszy obudzonej tchnieniem słów wiersza”. Cały szereg dramatycznych pytań kończy zwięzła deklaracja: „Nie wierzę"19.

„Ponure dni przedostatnie” opisane w dwu Traktatach o pewnym wieku oznaczają dla ,ja” lirycznego Urszuli Kozioł utratę dotychczasowych możliwości, także tych, które mieszczą się w rytuale codziennych czynności i działań: ,już się niedowidzi niedosłyszy niedomaga nie dojada nie dopuszcza nie dosypia nie dotrzymuje nie dopatruje nie dopowiada nie dopija nie dogryza nie dosala [...]"20.

Codzienną, konkretną sytuację przywołuje Urszula Kozioł, by zbudować w wierszu Igly stów szersze uogólnienie dotyczące późnego wieku:

cienką igłę nawlekam

zbyt grubą nitką

w rozpędzonym pociągu

zgubiłam okulary i nie wiem

przeszła przez ucho wreszcie

czy omsknęła się z ręki

takie jest moje życie ${ }^{21}$.

${ }^{16}$ Е. Багряна, Старата трепетлика (z tomu: Контрапункти, 1972), [w:] Избрана лирика в 2 тома, ред. Л. Исаева, София 1973, s. 170. W dalszej części zastosowany będzie skrót: Контрапункти.

${ }^{17}$ U. Kozioł, Ale to żaden powód, [w:] Supliki, Kraków 2005, s. 32. Dalej tom ten będzie oznaczony: Supliki.

${ }^{18}$ U. Kozioł, Maty traktat o Bożych niesprawiedliwościach, [w:] Supliki..., s. 15.

19 Ibidem, s. 16.

${ }^{20}$ U. Kozioł, Traktat o pewnym wieku II, [w:] Supliki..., s. 12.

${ }^{21}$ U. Kozioł, Igły snów, [w:] Supliki..., s. 46. 
Metaforycznym, zwięzłym ujęciem tego stanu jest początek wiersza bez tytułu: „stara rzeka nie ma siły/ doczołgać się do morza" 22 .

Od opisu fizycznych niedomogów już tylko jeden krok do określenia stanu ducha, który jest ich naturalną konsekwencją. Urszula Kozioł nie pozostawia wątpliwości:

W pewnym wieku bywają chwile, w których bezwzględnie czujesz się beznadziejny bezradny bezbronny beznamiętny bezbożny bezdomny bezbarwny bezsilny bezżenny bezpotomny bez ojca i matki bez jutra bezsensowny bezdenny [...] bezprzedmiotowy $i$ bezgranicznie zbezczeszczony przez swą bezbrzeżną zbędnośćc 23 .

Efektownie zestawiony szereg określeń zaczynających się od „bez”, przyimka podkreślającego brak, tworzy kompozycyjną całość z powtarzającym się w drugim Traktacie przeczeniem „nie”. Oba te z wirtuozerią ułożone Traktaty kończy poetka z ironicznym dystansem: „,więcej o tym w: wuwuwu srututu małpa kropa i szlus" 24 .

Szczególnej goryczy długowieczności doświadcza też w ekstremalnej sytuacji osobistej Elisaweta Bagriana. Wobec absurdalnej śmierci młodego wnuka stawia zasadnicze pytanie o sprawiedliwość losu; czuje się winna swojego sędziwego wieku, chętnie by oddała „swoje lata niezliczone, ostatni łyk i kęs”, ale też wie, że „в смъртта няма ни ред, ни отмяна"25.

W poezji Desanki Maksimović brak aż tak jednoznacznej erupcji gniewu i protestu wobec śmierci, nie ma aż tak bezwzględnej oceny konsekwencji psychicznych procesu starzenia się. Jak w całej niemal twórczości serbskiej poetki refleksje egzystencjalne, a w tym przypadku doświadczanie starości, mieszczą się w kręgu spraw zwyczajnych i typowych. W cytowanym wyżej liryku pod znamiennym tytułem Prvo smo dugo mislili (Najpierw dlugo myśleliśmy) jest mowa o tym, że w pewnym wieku w zupełnie odmienny sposób doświadcza się codzienności:

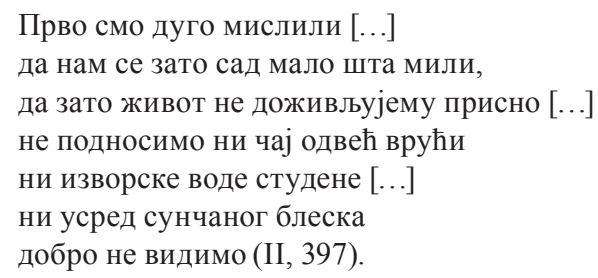

Objawy starzenia przejawiają się także w spowolnionym rytmie codziennych czynności („Све се peђе пише писмо,/ све чешће сећања беже,/ све радије се рано леже" (III, 297), jak w wierszu Budna kula, czy zmęczeniu (w wierszu Večernja tuga), które powoduje zagłębianie się w przeszłość. Podmiot lirycz-

\footnotetext{
${ }^{22}$ U. Kozioł, ***, [w:] Supliki..., s. 47.

${ }^{23}$ U. Kozioł, Traktat o pewnym wieku I, [w:] Supliki..., s. 12.

24 Ibidem.

${ }^{25}$ Е. Багряна, Триптих в черно. Безсилие, [w:] Контрапункти..., s. 205.
} 
ny zwraca się do młodszych: „Ви идите даље, / ja ћy се одморити на топлом бусену сећања" (III, 327).

Starość w poetyckim ujęciu serbskiej poetki nie jest jednak równoznaczna ze zobojętnieniem („,стари људи носе/ своју старост као рану”), сесhuje ją wzmożona wrażliwość: „стара се душа [...] боји да што пожели,/ разочарењима није рада" (Stare duše, III, 520). Dojmujące uczucie upływającego coraz szybciej czasu przenika wiele tekstów Desanki Maksimović, najpełniej dochodząc do głosu w tytułowym wierszu tomu Nemam više vremena, co było już przedmiotem szczegółowej analizy w innym miejscu ${ }^{26}$.

W pisanych pod koniec życia wierszach Elisawety Bagriany dojmujące poczucie nieuchronnego przemijania wyraża się, podobnie jak u Desanki Maksimović, w obserwacji najbliższego kręgu spraw codziennych. W wierszu Будилникът (Budzik) powtarzający się rytuał codziennego przebudzenia ze zmieniającymi się w zależności od pory roku obrazami za oknem, zamyka refleksja:

Ала в незнайна утрин,

в далечни или близки дни,

будилникът ми ще звънчи, звънчи,

но няма да запали неговият звън

зенице ми загасени ${ }^{27}$.

Gdy budzik, jak zwykle, zadzwoni, wszystko na zewnątrz będzie takie samo - choć źrenice oczu zgasną, życie będzie się toczyć w tym samym rytmie. Metaforyczny sens ma także samotna obserwacja zimowego pejzażu przez okno („Сега е черно-бяла графика пред мене”28), przeplatana wspomnieniami odległych w czasie barw lata. Nie ma jednak w tych reminiscencjach smutku, jest pogodzenie z losem. W liryku Познание (Poznanie) bułgarska poetka traktuje przemijanie jako naturalny proces zgodny z rytmem przyrody; każdy oczekiwany świt zabiera jeden z przyszłych dni, każdy dzień w nieunikniony sposób zmierza ku nocy. Ale czyż nie ma poranków — pyta poetka - których zorza pozostaje na zawsze; dni, w których słońce nie zachodzi; godzin, a nawet minut równych wieczności? Przebieg i tempo tych przemian zależą od sposobu przeżywania bodźców zewnętrznych. Otwarta postawa może ten naturalny rytm całkowicie odmienić: dni wypełnione słońcem nie przejdą w noc:

Дордето бие в мойта гръд несменният

часовник на крьвата,

нетърпеливо ще очаквам съмавнето

кроз нощта,

ще изживявам в дните си човешки

векове,

${ }^{26}$ Por. M. Semków, J. Semków, Starość w poetyckim zwierciadle Desanki Maksimović, [w:] Wielkie tematy kultury $w$ literaturach słowiańskich, „Slavica Wratislaviensia” CXLIII, Wrocław 2007, s. 119-128.

27 Е. Багряна, Будилникът, [w:] Контрапункти..., s. 217.

28 Е. Багряна, Двойно виждане от един зимен прозорец, [w:] Контрапункти..., s. 188-189. 
галактики, вселени ще узнавам

в земния ни свят,

by zakończyć tę liryczną deklarację porównaniem odwołującym się do prostego skojarzenia: „тъй както птица, на земята кацнала,/ небето пие/ от реката” 29.

$\mathrm{Z}$ analogicznym „odliczaniem” pozostałych lat, dni i godzin mamy do czynienia w wierszu Desanki Maksimović otwierającym cykl Peščani sat, ale beznamiętna na pozór obserwacja uciekających bezpowrotnie chwil i godzin wypełnionych okruchami codzienności („Отворим прозор, затворим врата... Упалим свећу, страницу књиге прочитам... осетим тренутну срећy”) kończy się jednoznacznie dramatycznym stwierdzeniem: „,о је део живота срушило у понор”(III, 73).

Pozostaje jeszcze zasadnicze dla tych rozważań pytanie: jaką strategię wobec postępującej starości proponują omawiane poetki? W pochodzącym z ostatnich lat życia serbskiej autorki tomie Zovina svirala została sformułowana kategoryczna deklaracja: „Nie dam się” (III, 511). Nieodparcie nasuwa się skojarzenie $\mathrm{z}$ niesłychanie popularnym w Jugosławii od początku lat siedemdziesiątych wierszem Arsena Dedicia Ne daj se, Ines, ne daj se godinama ${ }^{30}$. W liryku Desanki Maksimović w anaforycznym porządku głosi to każda kolejna strofa: „Не дам [...] да ми се за челом смире збивања [...] не дам чулима да се олене [...] на дам се у власт стварности шуре". Jednocześnie poetka wskazuje na wartości, które pragnie zachować: chce śnić na jawie, patrzeć głęboko w siebie, poznawać niedostępny innym świat dźwięków i obrazów, tęsknić i cierpieć.

Postawa buntu, zasygnalizowana już wcześniej, znajduje potwierdzenie w krótkim wierszu Urszuli Kozioł z omawianego tomu Supliki:

z rękami na plecach szybkim krokiem

lubię przekraczać ulicę w niedozwolonym miejscu

nie jestem dobrze ułożona

nie chcę być dobrze ułożona

starczy, że dobrze ułożona

zdążę być w trumnie ${ }^{31}$.

Spokojne pogodzenie się z losem sugeruje Страничка от неписан дневник (Stroniczka z niepisanego dziennika) Bagriany:

Аз имам всичко нужно

за ежедневието:

дом скромен, ала мой

и никому за нищо не дължа.

От блиските си сьм обичана -

и от приятелите, вярам,

29 Е. Багряна, Познание, [w:] Контрапункти..., s. 177.

${ }^{30}$ Wiersz znalazł się w tomie Brod u boci wydanym w 1971 roku, wykonywany był w formie melorecytacji przez Rade Seberdžiję, rychło stał się kultowym lirykiem kolejnych generacji w całej Jugosławii. Por. Arsen Dedić, http://www.poezijanoci.com/domaca/arsen-dedic-pesme.html\#0 [dostęp: 15.02.2015].

${ }^{31}$ U. Kozioł, Zamiast wiersza (II), [w:] Supliki..., s. 23. 
дори от непознати и далечни.

Съз здравето, за възрастта,

Добре сьм.

Сегиз-тогиз пьтувам -

не толкова и може би не там,

където бих желала,

но колко други нямат и това ${ }^{32}$.

Zrównoważony bilans codzienności ożywia świadomość wciąż żywej, pulsującej weny twórczej, „още жив на творчеството извора”33, choć coraz częściej serce ściska smutek, a wolę i pragnienia dosięga paraliż, męczy bezsenność. Poetka chciałaby to przezwyciężyć wszystkimi siłami rozumu. Aforystycznie sformułowane zakończenie nie pozostawia wątpliwości: „Не, не,/ не сьм нещастна, / ала да си нещастен —/ и да не си щастлив —/ не е едно и също..."34

W spokojnej rezygnacji z pretensji do losu pomaga bułgarskiej poetce witalizm obecny w jej twórczości przez całe życie ${ }^{35}$ : wystarczy, że wciąż jeszcze żywo bije jej serce. W nim skupiają się wszystkie płynące $\mathrm{z}$ zewnątrz bodźce zarówno te radosne, jak też przykre; ono - jak cudotwórca — przetwarza je na poezję. „...като чудотворец,/ който преврьща водата на вино,/ преврщаш ги на капки поезия" ${ }^{36}$, współbrzmi z troskami i radościami całego świata i dźwięczy jak muszla.

O ile Bagriana znajduje źródło aktywności, pozwalające zmierzyć się ze starością w bijącym wciąż żywo sercu, o tyle Desanka Maksimović szuka go w swojej psychice, w wyobraźni. Zamieszczony w tomie poetyckim Miholjsko leto ( $B a-$ bie lato) z 1987 roku liryk Rudnik sjaja (Kopalnia blasku) wykłada oczywiste dla poetki przekonanie oparte na porównaniu z płonącym wiecznie szybem:

Само сан песника гори,

машта његова вихори, стваралачка страст несита.

Само рудник тај не гасне

песник и у часе касне,

и у сну у њега хита (III, 284).

Po metaforę niegasnącego światła — - weny poetyckiej — sięga też serbska poetka w wierszu Budna kula (Latarnia morska) z tego samego zbioru: „Али има понеко огниште/ које године не униште,/ будне као светиља кула" (III, 297). Podobna myśl pojawia się też w liryku Kopač bunara z przedostatniego tomu poetki (1991). Przeprowadza ona rozbudowane porównanie człowieka kopiące-

32 Е. Багряна, Страничка от неписан дневник, [w:] Контрапункти..., s. 208.

33 Ibidem, s. 209.

34 Ibidem.

${ }^{35}$ Witalizm jako główny wyróżnik liryki Bagriany eksponuje Henryka Czajka w podręcznikowym zarysie literatury bułgarskiej. Por. H. Czajka, Literatura bułgarska, [w:] Dzieje literatur europejskich, red. W. Floryan, cz. II, t. 3, Warszawa 1991, s. 93-95.

${ }^{36}$ Е. Багряна, Мое сърие, [w:] Контрапункти..., s. 162. 
go studnię, poszukującego wody, z sobą - pragnącą odkryć tajemnice duszy. Człowiek ginie przysypany ziemią, która nie chce odkryć swoich tajemnic, a poetka drąży nadal, szukając siebie samej (,,ja и даље копам, копам,/ тражећ себе саму" [III, 502]).

W liryku Urszuli Kozioł świadomość zbliżającej się śmierci zawarta w metaforycznych obrazach sennych:

Miecz Damoklesa nad Madejowym łożem

oto są moje sny

głaz nad urwiskiem, którego kurczowo się trzymam

rusza się niby mleczny ząb w ustach dziecka ${ }^{37}$,

skonfrontowana zostaje z wciąż żywą umiejętnością postrzegania piękna natury: „i w każdej chwili na nowo/ umieram z zachwytu/ nad urodą tego świata/ choć ten właśnie wyślizguje mi się z rąk"38. Nieuchronnie nadciągający kres egzystencji spokojnie rejestruje wrocławska poetka w zamykającym tom Supliki wierszu Odchodzę:

Odurzona światłem tego świata

odchodzę

odurzona cieniem tego światła

odchodzę ${ }^{39}$.

Odejście oznacza - zgodnie z tytułem wiersza - wygaszanie, przemianę w kamień, ale nie jest równoznaczne z utratą zdolności postrzegania urody świata zewnętrznego:

urzeczona ogromem gwiazdy

pluskającej w maleńkiej kałuży

odchodzę

urzeczona powagą głazów

odchodzę ${ }^{40}$

U obu poetek z Bałkanów po zmaganiach z objawami nadchodzącej starości przychodzi czas jej spokojnego doświadczania. O ile we wcześniejszych lirykach traktujących o starości uwidacznia się zaskoczenie zachodzącymi zmianami, uświadomienie sobie nowej sytuacji życiowej, a u Urszuli Kozioł rozgoryczenie i bunt, o tyle w tych ostatnich jest precyzyjne opisanie stanu powolnego obumierania i to zarówno doświadczanego osobiście (u Desanki Maksimović: „radosti poblede”, „ožive ožiljci, ožive ozlede” [III, 232]), jak w kontaktach ze światem; to przerzedzające się szeregi bliskich i znajomych, zobojętnienie, igraszki pamięci, która przywołuje obrazy z odległej przeszłości. Senilia Desanki Maksimovićc1

${ }^{37}$ U. Kozioł, ***, [w:] Supliki..., s. 51.

38 Ibidem.

${ }^{39}$ U. Kozioł, Wygaszanie, [w:] Supliki..., s. 66.

${ }^{40}$ Ibidem, s. 68.

${ }^{41}$ Niezwykła aktywność twórcza serbskiej poetki przejawia się w licznych tomikach liryków wydawanych przez sędziwą autorkę w ostatnich latach życia: Nemam više vremena (1973), 
wypełnione są lirycznymi, pastelowymi obrazami przyrody, wspomnieniami z dzieciństwa w rodzinnej Brankovinie. W wierszu pod jednoznacznym tytułem Starenje z tomu Nebeski razboj (1991) znajdujemy bardzo osobiste podsumowanie własnego życia:
Написала сам се и начитала,
наслушала погрда и хвала,
нагледала лепоте и грдобе (...)
одолела некој боли
и на страшном месту понекад стала
плашила се људских зала (III, 501).

Ten pełen rezygnacji liryk kończy jednak przypomnienie obecnego przez całe życie entuzjazmu, optymizmu, których źródłem była zawsze wiosna i wolność: „Пролећу и слободи на сав глас се радовала” (III, 501). Mówienie pełnym głosem o niewyczerpanym bogactwie doznań jest próbą znalezienia satysfakcji nawet w późnej starości. Cytowany wyżej wiersz Ne dam kończy jednoznaczna deklaracja:

\footnotetext{
И на јави и кад сањам

волим у себе да гледам. [...]

живи ми се од слутње,

приче, хоћу да патим, чезнем, [...]

хоћу у невидљиво да гледам,

с душом да се играм жмуре" (III, 511).
}

Pozostaje też zadeklarowane jeszcze w cyklu Nemam više vremena przeświadczenie o trwałej spuściźnie, jaką będą ujęte w wiersze słowa:

Оставићу вам једино речи [...]

наслећене од ветрове фруле, [...]

отете с кљуна птици која лети над облацима, [...]

стихом оковане као древни инсект ћилибаром (II, 400).

Urszula Kozioł w wydanym ostatnio tomiku Horrendum ${ }^{42}$ wielokrotnie podejmuje temat swego rodzaju przymusu tworzenia. $\mathrm{Z}$ dystansem wobec siebie samej, postrzegając się z zewnątrz jako eksponat „w sam raz do muzeum figur starej daty”, świadoma zbliżania się nieuchronnego kresu, stwierdza: „Znowu dziś zapomniałam napisać Don Kichota/ już przestaję rozumieć siebie/ jak mogłam do tego dopuścić’43. Wiersz o Dickensie ułożony w pierwszej części w wy-

Slovo o ljubavi (1983), Mećaši sećanja (1983) Sajam reči (1987), Miholjsko leto (1987), Pamtiću sve (1988), Nebeski razboj (1991), Zovina svirala (1992). Interesujący nas temat starości, wyartykułowany szczególnie wyraźnie w pierwszym z wymienionych zbiorów, będzie obecny także w każdym następnym, choć późne senilia więcej mówią o postrzeganiu świata i poczuciu więzi z przyrodą.

\footnotetext{
${ }^{42}$ U. Kozioł, Horrendum, Kraków 2010.

${ }^{43}$ Ibidem, s. 11-12.
} 
liczankę pojedynczych słów łacińskich (,,amor, fervor, favor, rumor, tresor...”) kończy podzielane przez poetkę przesłanie „Do imionnika”:

Na przęsłach mostu — od słowa do słowa — zawieszam swój byt niech wiuwa na wietrze, niech uleci w powietrze

albo wyschnie na wiór i niech ze świata żywych

przejdzie do świata słowa

jeżeli mowa

zechce go czas jakiś zachować ${ }^{44}$.

Podsumowaniem refleksji o poetyckich rozważaniach trzech poetek o starości, autorek zachowujących do późnych lat wenę poetycką, poszukujących wciąż nowych środków ekspresji swego lirycznego ,ja” może być zakończenie liryku Do wiersza ${ }^{45}$ Urszuli Kozioł:

Wierszu mój powiedz wreszcie jak masz na imię czy ja cię znam a czy ty mnie znasz i czy na pewno mieszkasz tu czy nie tu gdzie szukać mam twoich kryjówek przyślij mi esemesa pilnie chciałabym spotkać się z tobą żeby się uwyraźnić na odchodnym.

\section{Bibliografia}

\section{Teksty źródłowe}

Bagriana E., Poezje, wybr. J. Śpiewak, przekł. zbior., Warszawa 1961.

Багряна Е., Контрапункти, [w:] Избрана лирика в 2 тома, ред. Л. Исаева. София 1973.

Багряна Е., Стихотворения, София 1986.

Kozioł U., Horrendum, Wydawnictwo Literackie, Kraków 2010.

Kozioł U., Supliki, Wydawnictwo Literackie, Kraków 2005.

Maksimović D., Poezje, wybór wierszy, przekład i posłowie G. Łatuszyński, Oficyna Wydawnicza Agawa, Warszawa 2013.

Максимовић Д., Целокупна дела (red. Д. Иванић), књига прва Т. III, edycja internetowa: http:// $\mathrm{zdm}$

\section{Opracowania}

Bois J.P., Historia starości. Od Montaigne'a do pierwszych emerytur, przeł. K. Marczewska, Oficyna Wydawnicza Volumen, Wydawnictwo Marabut, Warszawa 1996.

Bursztyńska H., Eliza Orzeszkowa - Dnie, prywatność starości, [w:] Dojrzewanie do petni życia. Starość w literaturze polskiej i obcej, Wydawnictwo UMCS, Lublin 2006, s. 238-246.
${ }^{44}$ Ibidem, s. 31.
45 Ibidem, s. 7-8.

Slavica Wratislaviensia 163, 2016

(C) for this edition by CNS 
Цанева М., Речник по нова българска литература (1978-1992), Хемус 1994, http://www.slovo. bg/showbio.php3?ID=183.

Cieślik A., Zubik A., Bańczarowska M., „,Starość” w narracjach kobiet w drugiej połowie życia, [w:] Starsze kobiety w kulturze i społeczeństwie, Wyd. MarMar, Wrocław 2005.

Czajka H., Literatura bułgarska, [w:] Dzieje literatur europejskich, red. W. Floryan, cz. II, t. 3, Warszawa 1991.

Dedić A., Ne daj se, Ines (1971), http://www.poezijanoci.com/domaca/arsen-dedic- pesme.html\#0.

Егерић М., Песништво Десанке Максимовић — призори лирске доброте и самилости, [w:] Д. Максимовић, Изабране песме, Београд 1998.

Janiak-Staszek A., „Więdnące” dziewczęta i ,krzepkie” matrony w twórczości Gabrieli Zapolskiej, [w:] Dojrzewanie do petni życia. Starość w literaturze polskiej i obcej, Wydawnictwo UMCS, Lublin 2006, s. 315-324.

Јеремић Драган М., Класични песник Десанка Максимовић, [w:] Д. Максимовић, Слово о љубави, Београд 2002.

[Kruk S., Flis-Czerniak E. red.], Dojrzewanie do petni życia. Starość w literaturze polskiej i obcej, Wydawnictwo UMCS, Lublin 2006.

Łapińska I., „Życiu zmiłowanie”. O starości w poezji Anny Kamieńskiej, [w:] Dojrzewanie do petni życia. Starość w literaturze polskiej i obcej, Wydawnictwo UMCS, Lublin 2006, s. 505-510.

Łatuszyński G., Pierwsza Dama poezji serbskiej, [w:] D.,Maksimović, Poezje, wybór wierszy, przekład i posłowie G. Łatuszyński, Oficyna Wydawnicza Agawa, Warszawa 2013.

Марковић Слободан Ж., Кюижевно стваралаштво Десанке Максимовић, Београд 1998.

Rydet Z., [w:] Zawadzka A., Ja jedna przedlużam życie, „Wysokie Obcasy” 10 maja 2008, nr 18 (471).

Semków M., Semków J., Starość w poetyckim zwierciadle Desanki Maksimović, [w:] Wielkie tematy kultury w literaturach stowiańskich, „Slavica Wratislaviensia” CXLIII, Wrocław 2007, s. $119-128$.

Straś-Romanowska M., Paradoksy rozwoju człowieka $w$ drugiej połowie życia a psychoprofilaktyka starości, [za:] A. Cieślik, A. Zubik, M. Bańczarowska, „Starość”, [w:] Starsze kobiety w kulturze i społeczeństwie, Wyd. MarMar, Wrocław 2005.

Вранеш А., Ђорђевић Љ., Литература о Десанки Максимовић, [w:] Д. Максимовић, Целокупна дела (уред. Д. Иванић) Т. X, edycja internetowa: http://zdm.nb.rs/dokumenti/tomIII.pdf.

[Zierkiewicz E., Łysiak A. red.], Starsze kobiety w kulturze i społeczeństwie, Wyd. MarMar, Wrocław 2005.

\section{Poetic deliberations on senescence written by women. Desanka - Urszula - Elisaweta}

\section{Summary}

In this work we analyse three poetic expressions by Elisaweta Bagriana, Desanka Maksimović and Urszula Kozioł who sincerely share with us the experience of their own senescence. The physical symptoms of ageing is perceived by Maksimovic with surpise, by Bagriana with understanding and by Kozioł with rebellion. The authors' state of mind differs from protest and frustration (Kozioł and Bagriana) to a peaceful surrender connected with understanding of what was meant to come. Each of the authors, regardless of all the differences between them, is able to be fruitful in their writing till their old age and is aware of what she has accomplished poetically, which makes the lives of all the three authors full of sense to them.

Keywords: self-reflection, senescence, surrender, passing away, power of poetry 


\section{Песничка расматрања о старости женском руком записана. Десанка - Уршула - Елисавета}

Резиме

Три велике песникиње: Елисавета Багрјана, Десанка Максимовић и Уршула Козјол у касним годинама живота искрено описују своје доживљавање старости. Физичке недостатке гледају са изненађењем (Максимовић), разумевањем (Багрјана) али такође са протестом и иронијом (Козјол). Расположење се колеба између бунта и горчине (Козјол, Багрјана) и помирења са судбином, свешћу неминовне пролазности. Свака песникиња, независно од разлика мећу њима, до касних година живота песнички активна, је свесна својих стваралачких могућности што даје смисао читавом животу.

Кључне речи: саморефлексија, старост, помирење, одлажење, моћ поезије 